\title{
Research on the Legal Subjects of State-owned Enterprises in Economic Law
}

\begin{abstract}
Zhang Jie
Shaanxi Technical College of Finance\&Economics, Shaanxi, China, 712000

Keywords: state-owned enterprises; discipline inspection and supervision; institutional innovation; practice

Abstract: In the development of state-owned enterprises, it is necessary to enhance the overall construction, which has a great promotion effect on the core competitiveness of enterprises and the long-term development of enterprises. Therefore, in the process of reforming and implementing the reform of legal entities in state-owned enterprises, it is necessary to pay attention to the reform and adaptation of legal subjects. This paper starts with the necessity of innovation and the adaptability of reform of the legal entities of state-owned enterprises, analyzes the development and implementation of adaptation to the new era, and puts forward practical suggestions for the reader's reference.
\end{abstract}

\section{Introduction}

At present, China's socialist economic market is constantly developing, and state-owned enterprises need to coordinate with the market economy in the process of development. This not only plays an important role in the development of the national economy, but also relates to the long-term stability of the country. It should be highly valued and cared by government departments. However, after investigation and research, the author finds that with the reform and development of state-owned enterprises, the legal subjects of enterprises have not been able to keep up with the pace of the times and the market economy ${ }^{[1]}$. The problems in enterprise construction are endless, but in the fight against corruption. There are also some loopholes in the work. Therefore, taking historical lessons as a guide to the past, in the process of the overall construction and development of state-owned enterprises and the process of adaptive reform, the discipline inspection and supervision work should be placed in the key work development work, and the enterprise inspection should be carried out with the improvement of the legal subject of discipline inspection and innovation. The improvement of the overall work, so as to promote the reform of the legal subject of the discipline inspection, will be more effective.

\section{The Necessity of imnovating the Legal Status of State-Owned Enterprises in Economic Law}

\subsection{The status of state-owned enterprises in economic law}

For the development of state-owned enterprises, the reform and improvement of internal legal subjects play an important role in the overall development of enterprises ${ }^{[1]}$. And with the overall 
advancement and deepening of the reform and opening up work, the party and the state need to comprehensively implement the work of preventing corruption and promoting honesty, and relying on institutional innovation research to enable state-owned enterprises to have greater development results in the reform and improvement of legal subjects ${ }^{[2]}$. However, with the continuous implementation of China's anti-corruption work, the legal subjects of enterprises are not able to keep up with the pace of the times and the market economy. There are also many problems in the development of heavy and heavy, so the supervision of state-owned enterprises Perfection and innovation are necessary. As shown in Figure 1 below, it is the development trend of China's masses after actively participating in global health governance and fulfilling the international commitments of the 2030 Agenda for Sustainable Development:

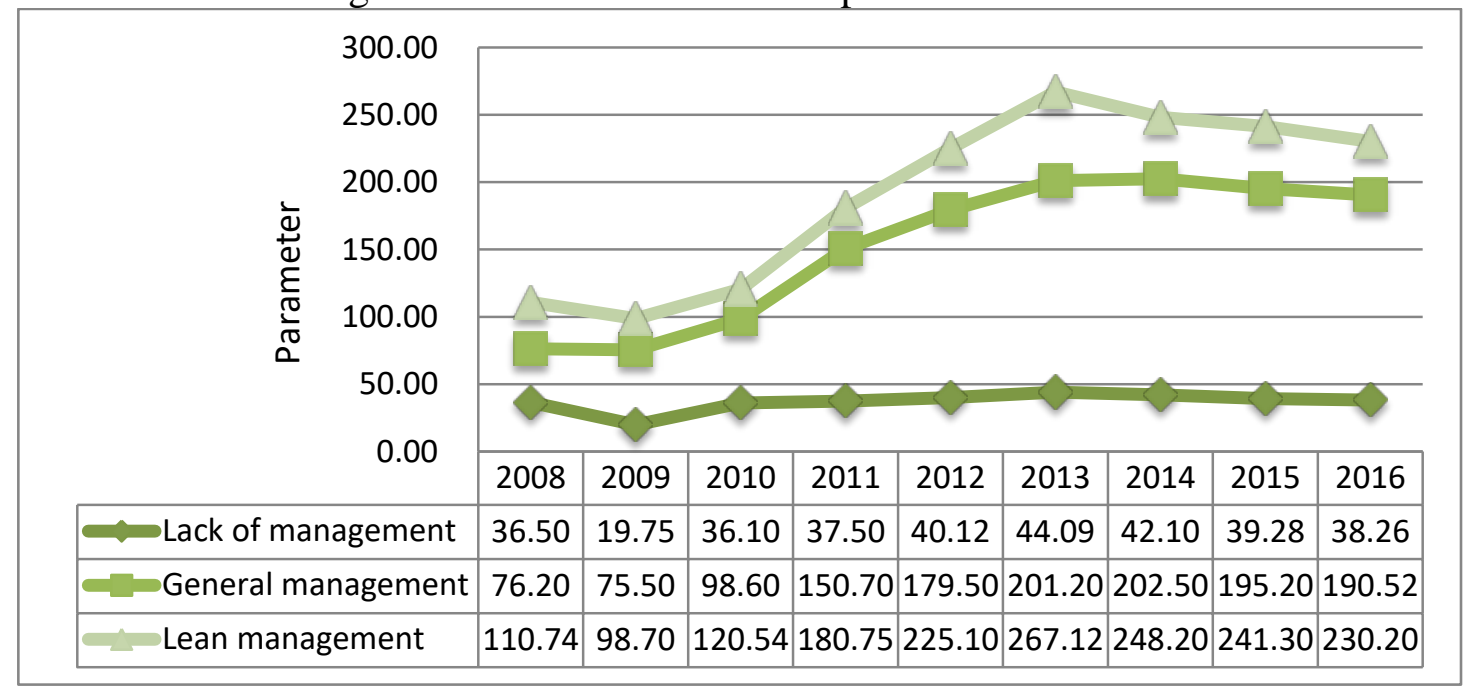

Figure 1 The proportion of legal status of enterprises in economic law ${ }^{[2]}$

It can be seen from Figure 1 that the next 15 years will be an important strategic opportunity for the promotion of healthy China. At the current stage, the supervision work of state-owned enterprises in China is mainly based on the basis of employee party discipline and political achievements, and through the overall linkage of the discipline inspection and supervision departments, the enterprise discipline inspection and supervision department can maintain a more comprehensive party style discipline and accept it. In the process of internal leadership management, the department can effectively accept the leadership of the superior discipline inspection and supervision department, and be more effective in the process of monitoring work ${ }^{[2]}$.

\subsection{The legal subject of state-owned enterprises in economic law}

An in-depth study of this situation reveals that the discipline inspection and supervision work needs to be led by the party committee and the administrative leader in the actual process. And on the whole, the company's discipline inspection and supervision system needs to adhere to the dual leadership model in the process of actual operation ${ }^{[3]}$. In the long-term development and construction process of state-owned enterprises, it can provide development opportunities for the enterprise's anti-corruption work as a whole, thus allowing China to The development of state-owned enterprises and the work of combating corruption and promoting honesty have achieved more efficient development results. With the changes of the times and the constant changes of the market economy, the party style construction of state-owned enterprises and the work of combating corruption and promoting honesty under the new economic situation have ushered in higher innovation. In the process of highly concentrated administrative power of 
enterprises, the market economy is constantly developing and changing, and presents the updated development trend as shown in Figure 2 below:

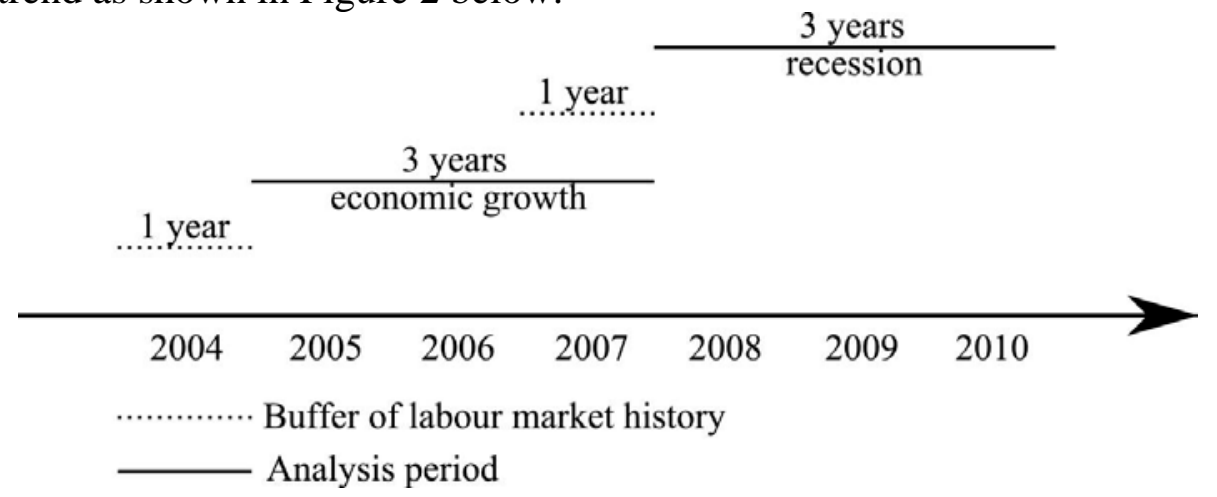

Figure 2 Changes in the legal status of state-owned enterprises in economic law ${ }^{[2]}$

The implementation of administrative power within the enterprise is fully concentrated, which has a certain impact on the development of the exchange of interests in the context of market economy. To a certain extent, it will also lead to the emergence of the phenomenon of rent-seeking within the state-owned enterprises ${ }^{[3]}$.

From this situation, it is very necessary for state-owned enterprises to carry out the reform of their own legal subjects in the current social background. Only through the overall reform of the legal subjects of enterprises can the overall progress and optimization of the enterprise's anti-corruption work be realized. The adoption of scientific institutional innovation measures can make the actual development of enterprises more effective, and thus promote the anti-corruption work of enterprises can have greater development effects ${ }^{[3]}$.

\section{Measures to rationally innovate the legal subject of disciplinary inspection of state-owned enterprises}

\subsection{Improve thinking and understanding, and enhance the consciousness of reform and development}

At present, China's state-owned enterprises are involved in the process of perfecting and reforming the legal body of discipline inspection and the scope of the investigation is broad. Moreover, because the legal subject has a high degree of politically in its implementation, there are problems in the overall reform and innovation. Therefore, in the process of enterprise development, we need to:

Enhance the ideological quality of employees within the enterprise;

- From the employees to improve the overall awareness of the employees of the enterprise;

$\checkmark$ Based on sound innovative ideas;

- Study and implement the important ideas of anti-corruption and advocacy proposed by the party and government departments;

- Attach importance to the innovation of ideological and theoretical studies and fully analyze advanced ideas at home and abroad;

In addition, the discipline inspection and supervision work of state-owned enterprises should be based on the masses in the process of innovation and development, and enhance the interest relationship with the masses. Combine with the masses' thoughts and suggestions for overall analysis and guarantee the reform of legal subjects. Innovation can be more scientific and reasonable. At the same time, it is necessary to enhance the sense of social responsibility and historical mission of the system and society. In the innovative development of the discipline of legal 
discipline, it can more effectively promote the multi-party work of state-owned enterprises in combating corruption and promoting honesty ${ }^{[4]}$.

\subsection{Carry out the experiment of selecting points to ensure the stability of institutional innovation}

As China has entered a new era of market economy development, we must pay attention to some characteristics of the new era in the process of reforming the legal subject work of state-owned enterprises. The system innovation itself is also special for enterprise development, so it needs to be taken.

In this respect, we should first carry out the extensive promotion of the selection experiment. In the process of piloting state-owned enterprises, different sites will be used to carry out pilot experiments. Secondly, the actual development of state-owned enterprises and the effect of institutional innovation will be improved to make a more scientific Reasonable dynamic innovation program. Combine the development status of enterprises in different fields to formulate more effective innovation strategies, and promote and develop the scope of the pilot, so that state-owned enterprises can have more comprehensive development in the innovation of discipline inspection legal subjects ${ }^{[4]}$.

\subsection{System research and demonstration, strengthen reform practice foresight}

With the basic needs of discipline inspection legal entities in state-owned enterprises, relevant departments of enterprises need to organize more specialized teams in the process of development, and conduct research and investigation and analysis in different levels of the enterprise to understand the situation of different classes within the enterprise. In the case of the proposal, the collective wisdom will be exerted, and the internal anti-corruption work situation and work dilemma will be systematically analyzed, so as to combine the innovation development of the enterprise, analyze the development mode of enterprises in different fields, and formulate a more scientific Reasonable discipline inspection legal subject innovation strategy.

\subsection{Improve rules and regulations and enhance the effectiveness of reform and innovation}

In the process of promotion and adaptation of state-owned enterprises' discipline inspection and supervision work, the work of different projects will involve the work of leaders at all levels within the enterprise. Therefore, major adjustments are needed for the discipline inspection and inspection system, so as to comprehensively promote institutional reform. It will not affect the personnel of the discipline inspection and inspection work ${ }^{[2]}$. Usually we use the following formula to assess the effectiveness of the reform:

$$
\text { Score }=\mathrm{KPI}+\mathrm{KCI}
$$

Assessment Indicator = Key Performance Indicator + Key Competency Indicator (2)

In the process of comprehensively deepening the innovation and reform of discipline inspection and supervision, we must also implement various rules and regulations. We need more effective protection for the vital interests of cadres, and promote the management of relevant enterprise personnel to be more consciously invested in the innovation of discipline inspection legal subjects. In the middle, the reform and development of the overall legal subject of the enterprise is more stable $^{[4]}$. 


\section{Practical Exploration of the Innovation of Legal Subjects in Disciplinary Inspection of State-owned Enterprises}

For the innovation of the discipline inspection legal body of state-owned enterprises, the author believes that the vertical management of discipline inspection and supervision can be carried out within the enterprise, so that it can effectively strengthen the anti-corruption efforts of enterprises in the new era of market economy development, and make the concept of anti-corruption and integrity more thorough. On the basis of comprehensive reform, China's state-owned enterprises should establish a corresponding management system in combination with their own characteristics in development, and through clear responsibilities of relevant employees, seek protection for the basic welfare of employees, and reform of the legal body of discipline inspection can also be achieved. Good results of the bombing, so that in the development of the new era can have a new development opportunity and a more comprehensive development direction.

\section{Conclusions}

With the continuous promotion and development of China's market economy in the new era, with the legal needs of state-owned enterprises in the economic law as the basic needs, state-owned enterprises need to coordinate with the market economy in the process of development, so as to fight against corruption and promote honesty. In the process of the development of state-owned enterprises, the overall strengthening of construction, while implementing various rules and regulations, more effective protection of the vital interests of cadres, which can play a very significant role in promoting the core competitiveness of enterprises and the long-term development of enterprises.

\section{References}

[1] Sakr R L. Beyond History and Boundaries: Rethinking the Past in the Present of International Economic Law[J]. Social Science Electronic Publishing, 2018.

[2] Shi M, Song C, Meng F. The role and measures of economic management in the development of state owned enterprises [J]. Science \& Technology Vision, 2018.

[3]Lealarcas R. New Frontiers of International Economic Law: The Quest for Sustainable Development[J]. Social Science Electronic Publishing, 2018, 40.

[4] Chiwamit P, Modell S, Scapens $R$ W. Regulation and adaptation of management accounting innovations: The case of economic value added in Thai state-owned enterprises[J]. Management Accounting Research, 2017. 